\title{
STUDENT PERCEPTIONS FOR DISTANCE EDUCATION AND EFFICIENCY ANALYSIS OF THE SYSTEM
}

\section{Ömer Faruk AKMEŞE $E^{1}$ \\ Emre DEMIR ${ }^{2}$ \\ Emre DÜNDER ${ }^{3}$}

Citation/O: Akmeşe, Ömer Faruk; Demir, Emre; Dünder, Emre (2016). Student Perceptions For Distance Education And Efficieny Analysis of the System, Hitit University Journal of Social Sciences Institute, Year 9, Issue 2, December 2016, pp.981-998

Abstract: With the increase in the number of universities and students requesting distance education as well as the development of Information Technologies, new institutions providing distance education have come up and this situation has made the research of the efficiency of distance education a more important issue. Considering the social and economic structure, population growth rate and young population as well as the number of students and academicians in our country, it is realized that distance education is of high importance for our country. The aim of this study is to evaluate the distance education used in the mutual courses in Hitit University in 2013-2014 educational term (Turkish Language, Ataturk's Principles and History of Turkish Revolution) by the students, to analyze the efficiency and to develop distance education system in accordance with these findings. Survey method has been used to measure the perceptions of the students for distance learning and to evaluate the system of distance learning. The sampling of the research has been conducted with 321 students chosen randomly and homogeneously among 4000 students actively studying in the faculties, graduated from schools and vocational schools of Hitit University.

Keywords: Efficiency Analysis, Distance Education Perception.

Makale Geliș Tarihi: 23. 08. 2016/ Makale Kabul Tarihi: 08.11.2016

1 Öğr. Gör., Osmancık Ömer Derindere Meslek Yüksek Okulu, e-posta: ofarukakmese@hitit.edu.tr.

2 Öğr. Gör., Osmancık Ömer Derindere Meslek Yüksek Okulu, e-posta: emredemir@hitit.edu.tr

3 Arş. Gör., Ondokuz Mayıs Üniversitesi Fen-Edebiyat Fakültesi, İstatistik Bölümü, e-posta: emre.dunder@gmail.com 


\section{Uzaktan Öğrenim İçin Öğrenci Algılıkları ve Sistemin Verimliliği Analizi}

Atıf/O: Akmeşe, Ömer Faruk; Demir, Emre; Dünder, Emre (2016). Uzaktan Öğrenim İçin Öğrenci Algılıkları ve Sistemin Verimliliği Analizi, Hitit Üniversitesi Sosyal Bilimler Enstitüsü Dergisi, Yıl 9, Sayı 2, Aralık 2016, ss. 981-998

Özet: Ülkemizde üniversite sayısının ve uzaktan eğitimi talep eden öğrenci sayısının artması ve bilişim teknolojilerinin gelişimi ile beraber uzaktan eğitim veren kurumlara yenileri eklenmiş ve bu durum uzaktan eğitim sistemlerinin verimliliğinin araştırılmasını daha önemli kılmıştır. Ülkemizin sosyal ve ekonomik yapısı, nüfus artış hızı, genç nüfusu ve öğrenci sayısı, üniversitelerimizdeki akademisyen sayıları gibi etkenler göz önüne alındığında uzaktan eğitim ülkemiz açısından büyük önem arz etmektedir. Bu çalışmada, Hitit Üniversitesi'nde 2013-2014 eğitim ögrretim yılında okutulan ortak derslerin (Türk Dili, Atatürk İlkleri ve İnkılap Tarihi) yürütülmesinde kullanılan uzaktan eğitim siteminin öğrenciler tarafindan değerlendirilmesi, verimliliğinin analiz edilmesi ve bu doğrultuda bulgular sonucunda uzaktan eğitim sisteminin geliştirilmesi amaçlanmıştır. Öğrencilerin uzaktan eğitim algıların ölçmek ve uzaktan eğitim sistemini değerlendirmek için anket yöntemi kullanılmıştır. Araştırmanın örneklemini, Hitit Üniversitesi bünyesindeki tüm Fakülte, Yüksekokul ve Meslek Yüksekokullarinda aktif olarak eğitim gören toplam 4000 ögrrenciden rastgele ve homojen olarak seçilen 321 ögrenci oluşturmuştur.

Anahtar Kelimeler: Verimlilik Analizi, Uzaktan Eğitim Algısı.

\section{INTRODUCTION}

Distance education can briefly be defined as a corporate learning activity combining students, teachers and teaching materials in different places through communication technologies. Considering today's conditions, it is a rational, modern and innovative educational system in which the education and training pass through computers rapidly. Web-based distance education provides students access to the educational materials, regardless of the time spent by bringing the students and instructors together in the virtual classrooms and regardless of the space via benefiting from the opportunities of internet technology. Among some advantages which are not included in formal education are the ability to repeat the lessons as much as the student wishes, and to be able to access all course materials at any time. In addition, distance education also contributes to the lifelong education of individuals by giving 
opportunity to people with limited time and financial opportunities and to working people. To summarize, distance education applications provide great flexibility and convenience in terms of time, space, equipment, learners and teachers through developed web technologies.

People have begun to benefit from the technological possibilities since the 20th century. The information obtained has begun to reach more people, the information generated has begun to spread, and the learning and teaching activities have begun to reach out to the masses rather than being a privilege (Al \& Madran, 2004: 263).

Distance learning has a history of more than a century. The journey that began with letters sent by mail has developed through radio, television, video, conferences and web-based applications over time. Adapting and leading in this technology is undoubtedly significant in terms of following the development of educational activities around the world. Nowadays, the innovations that came along with the distance education model contribute to formal education. Some educational institutions have completely adopted this model.

In the theoretical part of this study, Distance Education and Distance Education System concepts are stated. In the application part, a survey was conducted to reevaluate the distance education system and to measure the students' perception of the system. In the survey, questions about their perception of the distance education division, evaluation of the course contents, their motivations, their attitudes towards the teaching staff, the comparison between formal and distance education, accessibility to distance education software issues in the process of distance learning activities are directed to students and their responses were recorded. Students' responses to the questions were analyzed within the computer with the data analysis software package, SPSS (version 22.0). In the process of data analysis, frequency distribution of the responses was calculated and comments were made on the results obtained. Additionally, a Reliability and Factor Analysis was conducted. Relations between some of the questions were examined with the chi-square analysis. In the conclusion part, students' benefits from the content prepared for distance education ratios were determined as a result of the analyses, the evaluation of content intended for distance education is made and the study is concluded by representing suggestions on solutions to the problems encountered in the distance education applications and submitting proposals especially for the most suitable distance education model for common courses taught in universities. 


\section{DISTANCE EDUCATION}

Many definitions of distance education are provided in the related literature. According to the description from the United States Distance Learning Association (USDLA), distance education is the transmission of education to the remote students with the help of tools such as satellite, video, audio, graphics, computer and multi-media technology. (Kaya \& Uluğ, 1997).

All of the applications performed in environments where teachers and students are independent from each other in terms of the time and space is defined as “distance learning”. (Verduce, Clark \& Maviş 1994).

Considering the similar definitions in the literature, distance education is a teaching method where;

- It consists of individuals who have not had the opportunity of getting traditional teaching methods,

- Teachers and students are in different environments,

- The time and the age of learning is flexible,

- It is composed of specially created units and materials,

- Technologies such as printed materials, radio, television and computers are used as teaching tools,

- High level communication is provided between teachers and students (Coşkun, 2007).

The needs for distance education can be briefly stated as follows (Şen Atasoy \& Aydin, 2010: 2):

- To deliver educational services to more people.

- To ensure the equality of opportunity and possibility in education.

- To take advantages of experts from different places.

- To meet the educational needs of students who cannot come to school because of their interests, abilities, ages, jobs and geographical conditions.

- To eliminate the limitations of traditional education by providing each individual the opportunity to learn in the method and at the speed, to some extent, he wishes.

According to a statement made by Turkey Statistical Institute (TSI), although Turkey has a population that is aging gradually, it has a rather young 
population compared with European countries. Children and young people compose $41.1 \%$ of Turkey's population. Compared with the European Union member countries, Turkey has the youngest population with $16.6 \%$, while Spain and Italy have the least young population with 9.9\% (TSI, 2014). The young population Turkey has great potential for the future of the country. Increasing the scope and quality of education will divert this potential in a positive direction. Otherwise, in the case of inadequate and unqualified training, the young population of the country could turn into a resource of problem. Therefore, it is necessary to take advantage of distance learning which is a modern and innovative teaching method, and to use it in the most effective manner. Also, when taking Turkey's socio-economic status into consideration, equality of opportunity can be provided to students, especially in rural areas, through the distance learning method. Thus, it becomes possible to overcome the limitations of the individuals who wish to receive training. (Akmeşe, 2015: 8)

\section{METHOD}

The use of distance education seems to question traditional educational approaches significantly. Serious discussions on which teaching methods are effective among traditional education, distance education and the use of a combination of both (hybrid) are made. While these discussions were once reactional, they have become the subjects for scientific research over time. Some of the findings suggest that distance education is more efficient in every way when compared to the traditional education system (Shachar \& Neumann, 2003), and some of the findings suggest there are pros and cons to both systems. (Lionarakis \& Papademetriou, 2003; Antalyal1, 2004: 28)

Within our research, statistical analyses were made by using SPSS (Version 22.0, SPSS Inc., Chicago, IL, USA; undergraduate, Hitit University) package program. Descriptive statistics were presented in number and percentage. Relationships between the categorical variables were researched by the chisquare test. Cronbach Alfa reliability analysis was performed to evaluate the reliability of the survey. Reliability coefficients that will be obtained when the scale materials are deleted, are calculated separately. Factor analysis was carried out for the construct validity. Conformity of the data with the factor analysis and the correlation testing between the variables were examined by Kaiser-Meyer-Olkin (KMO) and Barlett Sphericity Test. Principal Components method and varimax rotation were used to identify the factors. Factors with the eigenvalue larger than 1 were evaluated. For the statistical significance level, $\mathrm{p}$ was rated as $\mathrm{p}<0.05$. 


\section{APPLICATION}

\section{A. Analysis and Evaluation of Data Obtained from the Study}

The survey was conducted with 321 students selected randomly and homogeneously from the 4000 total students studying actively in the Class 1 level in all faculties, schools and vocational schools within Hitit University. Since the courses given in distance education system in Hitit University are first class lessons, the survey was conducted only on first year students. Surveys were applied directly to the participants, and interviewers made public statements when necessary. The survey was developed by evaluating the materials used in the literature to determine the opinions and expectations of students for the effectiveness of distance education, and it was prepared in two parts. The first part was composed of demographic and descriptive questions and the second part was composed of questions that would be the base of the analyses and prepared according to the five-point Likert scale. The items the participants left blank marked the same expression were not taken into consideration. $56.7 \%$ of the students surveyed are undergraduate students and $43.3 \%$ of them are graduate students.

\section{B. Demographic Characteristics of Students Participating in the Survey and Frequency Analysis of First Part Survey Items}

A frequency analysis regarding the gender, age level and school situation of the participants was made. Frequency analysis results of the faculties and schools of students who participated in the study are shown in Table 1. Among the 321 students who participated in the study, 182 are studying in undergraduate programs and 139 are studying in graduate programs.

Table 1. School information of the students joining the survey

\begin{tabular}{|c|c|c|}
\hline Type of School & Frequency & Frequency \% \\
\hline Faculty of Arts and Sciences & 50 & 15,6 \\
\hline $\begin{array}{c}\text { High School of Physical Education and } \\
\text { Sports }\end{array}$ & 18 & 5,6 \\
\hline Engineering Faculty & 14 & 4,4 \\
\hline Vocational High School & 50 & 15,6 \\
\hline Osmancik Vocational High School & 42 & 13,1 \\
\hline Alaca Vocational High School & 24 & 7,5 \\
\hline Sungurlu Vocational High School & 66 & 20,6 \\
\hline Faculty of Economics Administrative and & 29 & 9 \\
\hline Social Sciences & 28 & 8,7 \\
\hline Faculty of Theology & 321 & 100 \\
\hline Sum & & \\
\hline
\end{tabular}

986 Hitit Üniversitesi Sosyal Bilimler Enstitüsü Dergisi - YIl 9, Sayı 2, Aralk 2016 
Frequency analysis results based on the age status of the students participating in the survey is given in Table 2. Since the students surveyed consist of first class students, it can be said that most of the students are in the range of 18 and 22 years of age.

Table 2. Age status of students participating in the survey

\begin{tabular}{|c|c|c|c|c|c|}
\hline Age & Frequency & Frequency $\%$ & Age & Frequency & Frequency \% \\
\hline 17 & 1 & 0.3 & 24 & 2 & 0.6 \\
\hline 18 & 31 & 9.7 & 26 & 3 & 0.9 \\
\hline 19 & 98 & 30.5 & 29 & 1 & 0.3 \\
\hline 20 & 109 & 34.0 & 30 & 1 & 0.3 \\
\hline 21 & 42 & 13.1 & 37 & 1 & 0.3 \\
\hline 22 & 23 & 7.2 & 48 & 1 & 0.3 \\
\hline 23 & 7 & 2.2 & 51 & 1 & 0.3 \\
\hline
\end{tabular}

Frequency analysis results based on the gender status of students participating in the survey are given in Table 3 . Hereunder, it is seen that the number of female and male students are approximate.

Table 3. Distribution of students participating in the survey by Gender

\begin{tabular}{|c|c|c|}
\hline Gender & Frequency & Frequency \% \\
\hline Female & 165 & 51.4 \\
\hline Male & 156 & 48.6 \\
\hline
\end{tabular}

According to Table 4, it can be seen that students spend approximately 1 hour $(30.6 \%)$ on the internet. They stated that they use internet mostly for research and education $(28.7 \%)$. 
Table 4. Percentage (\%) Distribution of students according to HUZEM system and their internet usage

\begin{tabular}{|c|c|c|c|c|}
\hline \multicolumn{5}{|c|}{ How much time do you spend in Internet daily? } \\
\hline None & About 1 hour & About 2 hours & About 3 hours & $\begin{array}{c}4 \text { hours and } \\
\text { more }\end{array}$ \\
\hline $14.8 \%$ & $30.6 \%$ & $20.9 \%$ & $11.3 \%$ & $22.5 \%$ \\
\hline \multicolumn{5}{|c|}{ For which purpose do you use the Internet mostly? } \\
\hline $\begin{array}{c}\text { Research and } \\
\text { Training }\end{array}$ & Entertainment & News & Social Media & Other \\
\hline $28.7 \%$ & $13.9 \%$ & $12.8 \%$ & $32 \%$ & $12.7 \%$ \\
\hline \multicolumn{5}{|c|}{ How frequently do you log into HUZEM distance education system? } \\
\hline Once in a day & Once in a week & $\begin{array}{l}\text { Once in two } \\
\text { weeks }\end{array}$ & $\begin{array}{c}\text { Once in three } \\
\text { weeks }\end{array}$ & $\begin{array}{l}\text { Once in a } \\
\text { month }\end{array}$ \\
\hline $13.3 \%$ & $14.1 \%$ & $14.1 \%$ & $11.2 \%$ & $47.2 \%$ \\
\hline \multicolumn{5}{|c|}{ Do you use HUZEM distance education system? } \\
\hline & & & Yes & No \\
\hline & & & $68.7 \%$ & $31.3 \%$ \\
\hline
\end{tabular}

According to Table 5, students stated that they mostly use pdf (44.4\%) among the documents in HUZEM education system. Next, Video (28.7\%) and mp3 (4.8\%) were used. $22.1 \%$ of the students stated that they use all of the documents.

Table 5. Percentage (\%) distributions of opinions and expectations of students related to exams, presentation of the courses, content and the materials of HUZEM

\begin{tabular}{|c|c|c|c|}
\hline \multicolumn{3}{|c|}{ Which HUZEM distance education system documents are you using? } \\
\hline Document(pdf) & Presentation (Video) & Mp3 & All Files \\
\hline $44.4 \%$ & $28.7 \%$ & $4.8 \%$ & $22.1 \%$ \\
\hline
\end{tabular}

According to Table 6, students remarked that the web site of HUZEM is usually very easy (18.9\%), easy (33\%) and somewhat easy (35.7\%). 34.6\% of students stated that their computer and internet infrastructure is adequate to a certain degree. 
Table 6. Percentage (\%) Distributions of Students' Opinions and Expectations related to HUZEM infrastructure

\begin{tabular}{|c|c|c|c|c|}
\hline \multicolumn{5}{|c|}{ Please evaluate the use of HUZEM distance education website. } \\
\hline Very Easy & Very Easy & Easy & Moderate & Difficult \\
\hline $18.9 \%$ & $18.9 \%$ & $33 \%$ & $35.7 \%$ & $6.6 \%$ \\
\hline \multicolumn{5}{|c|}{ Do you think that the capability to use the computer and internet at Hitit } \\
\hline $\begin{array}{c}\text { Very } \\
\text { Sufficient }\end{array}$ & Very Sufficient & Sufficient & $\begin{array}{l}\text { Partially } \\
\text { Sufficient }\end{array}$ & Insufficient \\
\hline $11.3 \%$ & $11.3 \%$ & $27.2 \%$ & $34.6 \%$ & $12.8 \%$ \\
\hline
\end{tabular}

According to Table 7 , most of the students seem to lean towards face to face education more.

Table 7. Percentage (\%) Distributions of Students' Opinions and Expectations on distance education and classroom education

Please evaluate HUZEM distance education system by comparing it to face-to-face

\begin{tabular}{|c|c|c|c|c|}
\hline $\begin{array}{c}\text { Very } \\
\text { Efficient }\end{array}$ & Efficient & $\begin{array}{l}\text { Partially } \\
\text { Efficient }\end{array}$ & Inefficient & Very Inefficient \\
\hline $8.8 \%$ & $21.6 \%$ & $27.2 \%$ & $23.1 \%$ & $19.3 \%$ \\
\hline
\end{tabular}

Which one is the most appropriate of the following three options for you?

\begin{tabular}{|l|c|c|c|}
\hline \multirow{2}{*}{} & In classroom & In classroom \\
education only & Distance & $\begin{array}{c}\text { education } \\
\text { and distance } \\
\text { education only } \\
\text { education } \\
\text { together }\end{array}$ \\
\hline & $40.3 \%$ & $21.7 \%$ & $38 \%$ \\
\hline
\end{tabular}

Do you prefer the formal education given in classroom face-to-face or the distance

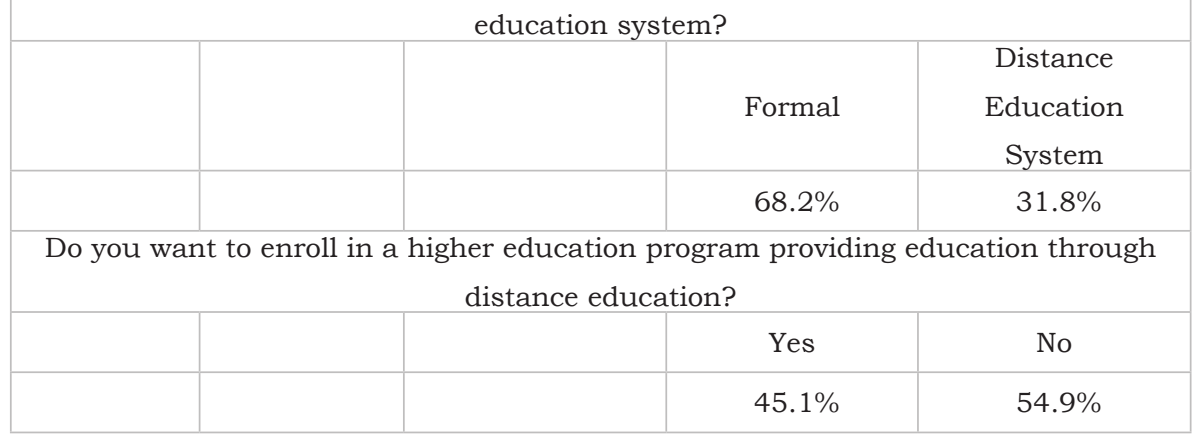


According to Table 8, students responded to the question of determining the content and objectives of the courses at the beginning of the semester as good $(32.7 \%)$ and normal (32.9\%). While $80.2 \%$ of the students stated that they are not able to communicate adequately with the instructors in charge of the distance education system, $46.3 \%$ of them remarked that they could get help to a certain extent and $38.2 \%$ indicated that they were not able to get adequate help.

Table 8. Percentage (\%) Distributions of Opinions and Expectations of Students on Course Contents, Help and Contact Topics in HUZEM

Evaluate the content and objectives of the courses, specified in the beginning of the semester in HUZEM distance education system.

\begin{tabular}{|c|c|c|c|c|}
\hline \multirow{2}{*}{ Excellent } & Good & Moderate & Bad & Poor \\
\hline $13.3 \%$ & $32.7 \%$ & $32.9 \%$ & $11 \%$ & $10 \%$ \\
\hline
\end{tabular}

Can you communicate adequately with instructors in HUZEM distance education

\begin{tabular}{|l|c|c|c|c|}
\hline & & & \multicolumn{3}{|c|}{ system? } \\
\hline & & & $19.8 \%$ & Yes \\
\hline \multicolumn{5}{|c|}{ Can you get sufficient help for your questions and requests? } \\
\hline & & I get help & I partially get help & I cannot get help \\
\hline & & $15.5 \%$ & $46.3 \%$ & $38.2 \%$ \\
\hline
\end{tabular}

\section{Frequency Analysis of the replies to the Survey questions in Likert Scale Reliability Analysis}

Frequency percentages of some of the 22 questions that will be used in the reliability analysis, factor analysis and chi-square analysis in the second part of the survey are given in Table 9 . 
Table 9. Frequency Analysis (\%)

\begin{tabular}{|c|c|c|c|c|}
\hline $\begin{array}{l}\text { Strongly } \\
\text { Agree }\end{array}$ & Agree & $\begin{array}{l}\text { Partially } \\
\text { Agree }\end{array}$ & Disagree & $\begin{array}{l}\text { Strongly } \\
\text { Disagree }\end{array}$ \\
\hline \multicolumn{5}{|c|}{$\begin{array}{l}\text { The content of the course taken in HUZEM distance education being always } \\
\text { accessible shortened my learning process. }\end{array}$} \\
\hline $19.7 \%$ & $25.6 \%$ & $21.9 \%$ & $14.9 \%$ & $17.9 \%$ \\
\hline \multicolumn{5}{|c|}{ HUZEM distance education system has increased my educational motivation. } \\
\hline $10.7 \%$ & $18 \%$ & $22.1 \%$ & $23.8 \%$ & $25.4 \%$ \\
\hline \multicolumn{5}{|c|}{$\begin{array}{l}\text { The HUZEM distance education system is advantageous in allow me to gather } \\
\text { information when and from where I want. }\end{array}$} \\
\hline $15.2 \%$ & $23.2 \%$ & $23.4 \%$ & $18.9 \%$ & $19.3 \%$ \\
\hline \multicolumn{5}{|c|}{$\begin{array}{l}\text { I think that HUZEM distance education system has increased my understanding c } \\
\text { individual responsibility. }\end{array}$} \\
\hline $12.7 \%$ & $19.2 \%$ & $24.7 \%$ & $25.4 \%$ & $18 \%$ \\
\hline \multicolumn{5}{|c|}{$\begin{array}{l}\text { I had the chance to spend more time on my other classes thanks to lessons I took } \\
\text { in HUZEM distance education system. }\end{array}$} \\
\hline $26.5 \%$ & $19.6 \%$ & $21.2 \%$ & $16.5 \%$ & $16.3 \%$ \\
\hline \multicolumn{5}{|c|}{$\begin{array}{l}\text { The courses taken in HUZEM distance education system have improved my } \\
\text { knowledge and skills. }\end{array}$} \\
\hline $10.1 \%$ & $19 \%$ & $28.2 \%$ & $21.3 \%$ & $21.3 \%$ \\
\hline \multicolumn{5}{|c|}{$\begin{array}{l}\text { I have been able to develop my use of computer technology by taking classes in } \\
\text { HUZEM distance education system. }\end{array}$} \\
\hline $11 \%$ & $17.4 \%$ & $25.3 \%$ & $24.6 \%$ & $21.8 \%$ \\
\hline \multicolumn{5}{|c|}{ I benefit from the contents prepared in the HUZEM distance education system. } \\
\hline $13.6 \%$ & $23.2 \%$ & $27 \%$ & $19.3 \%$ & $16.9 \%$ \\
\hline \multicolumn{5}{|c|}{$\begin{array}{l}\text { HUZEM distance learning exam questions have similarities with the course } \\
\text { content. }\end{array}$} \\
\hline $19.3 \%$ & $29.8 \%$ & $24.3 \%$ & $13.4 \%$ & $13.2 \%$ \\
\hline \multicolumn{5}{|c|}{$\begin{array}{l}\text { HUZEM distance education weekly course topics were carried out according to the } \\
\text { weekly topic distribution specified for the course. }\end{array}$} \\
\hline $15.8 \%$ & $33.1 \%$ & $25.1 \%$ & $12.9 \%$ & $13.1 \%$ \\
\hline \multicolumn{5}{|c|}{$\begin{array}{l}\text { In HUZEM distance education, the presentation (video) lecturer of the course is } \\
\text { speaking properly and in an understandable manner. }\end{array}$} \\
\hline $19.3 \%$ & $26 \%$ & $25.6 \%$ & $13.9 \%$ & $15.3 \%$ \\
\hline \multicolumn{5}{|c|}{$\begin{array}{l}\text { HUZEM distance education exam questions and the evaluations made are qualified } \\
\text { enough to measure my success. }\end{array}$} \\
\hline $18 \%$ & $26 \%$ & $29 \%$ & $13.2 \%$ & $13.9 \%$ \\
\hline \multicolumn{5}{|c|}{ Courses in HUZEM distance education system are supported by current issues. } \\
\hline $11.8 \%$ & $24.6 \%$ & $32.3 \%$ & $16.6 \%$ & $14.6 \%$ \\
\hline \multicolumn{5}{|c|}{ I want to take the HUZEM distance education exams on the Internet. } \\
\hline $20.4 \%$ & $14.9 \%$ & $14.9 \%$ & $20 \%$ & $29.8 \%$ \\
\hline
\end{tabular}




\section{Reliability Analysis}

Cronbach's alpha reliability analysis was performed to measure the reliability of the survey. The reliability coefficient regarding the scale of distance education is calculated as 0.885 . Hence, the survey was determined to be highly reliable at $88.5 \%$ level.

Table 10. Cronbach's Alpha Coefficients Regarding Survey Items

\begin{tabular}{|c|c|c|c|}
\hline Item & $\begin{array}{c}\text { Cronbach's Alpha } \\
\text { Coefficient without Item }\end{array}$ & Item & $\begin{array}{c}\text { Cronbach's } \\
\text { Alpha Coefficient } \\
\text { without Item }\end{array}$ \\
\hline s1 & 0.881 & s12 & 0.877 \\
\hline s2 & 0.875 & s13 & 0.890 \\
\hline s3 & 0.876 & s14 & 0.879 \\
\hline s4 & 0.876 & s15 & 0.877 \\
\hline s5 & 0.887 & $s 16$ & 0.883 \\
\hline s6 & 0.875 & s17 & 0.877 \\
\hline s7 & 0.874 & s18 & 0.877 \\
\hline s8 & 0.881 & $s 19$ & 0.888 \\
\hline s9 & 0.875 & $s 20$ & 0.890 \\
\hline s10 & 0.875 & $s 21$ & 0.886 \\
\hline s11 & 0.897 & $s 22$ & \\
\hline
\end{tabular}

Reliability coefficients that would be obtained when the scale items are deleted are shown in the table above. Referring to the results, no substantial difference is observed between the existing reliability coefficient and reliability coefficient that would be obtained. Accordingly, all scale questions are included in the analysis at the stage of reliability analysis.

\section{E. Factor Analysis}

Factor analysis was applied onto 22 questions contained in the scale of distance education in order to reduce the size. 
Table 11. Test Values of Factor Analysis

\begin{tabular}{|c|c|c|}
\hline \multicolumn{2}{|c|}{ Kaiser-Meyer-Olkin Measure of Sampling Adequacy } & .940 \\
\hline Chi-square statistic & 2832.123 & $\begin{array}{c}\text { Chi-square } \\
\text { statistic }\end{array}$ \\
$\begin{array}{c}\text { Degree of } \\
\text { Freedom }\end{array}$ \\
\hline Significance & 120 & Significance \\
\hline
\end{tabular}

Bartlett's sphericity and KMO sampling adequacy test results are shown above regarding the responses to the scale of distance education. Significant correlation between variables was determined according to the Bartlett's sphericity test results $(\mathrm{p}<0.05)$. The scale was determined to be approximately 94\% appropriate to factor analysis according to KMO statistic.

Table 12. Test Values of Factor Analysis

\begin{tabular}{|c|c|c|c|c|}
\hline Component & Eigenvalue & \multicolumn{3}{|c|}{ Sum of Loadings' Squares after Rotation } \\
\hline & Total & Total & Variances\% & $\begin{array}{c}\text { Cumulative } \\
\%\end{array}$ \\
\hline 1 & 7.733 & 7.659 & 47.866 & 47.866 \\
\hline 2 & 1.426 & 1.501 & 9.379 & 57.245 \\
\hline
\end{tabular}

When the table is examined, 2 factors were determined of which eigenvalues are greater than 1 according to the factor analysis results. The factors of which eigenvalues are smaller than 1 are not shown in the table. The 2 factors obtained explain $57.245 \%$ of the total variability.

Table 13. Test Values of Factor Analysis

\begin{tabular}{|c|c|c|}
\hline Item & 1 & \\
\hline & 0.846 & \\
\hline $\mathrm{s} 7$ & 0.814 & \\
\hline $\mathrm{s} 9$ & 0.812 & \\
\hline $\mathrm{s} 6$ & 0.809 & \\
\hline $\mathrm{s} 2$ & 0.803 & \\
\hline $\mathrm{s} 4$ & 0.795 & \\
\hline $\mathrm{s} 10$ & 0.793 & \\
\hline $\mathrm{s} 18$ & 0.779 & \\
\hline $\mathrm{s} 3$ & 0.714 & \\
\hline $\mathrm{s} 15$ & 0.702 & \\
\hline $\mathrm{s} 19$ & 0.689 & 0.795 \\
\hline $\mathrm{s} 12$ & 0.674 & 0.818 \\
\hline $\mathrm{s} 17$ & 0.525 & 0.814 \\
\hline $\mathrm{s} 16$ & & 0.802 \\
\hline $\mathrm{s} 20$ & & \\
\hline $\mathrm{s} 21$ & & \\
\hline
\end{tabular}


5 questions which are not suitable for factor analysis according to the rotated components matrix were removed and by the last factor analysis performed the total of 17 questions were grouped under two factors. About $58 \%$ of total variability could be explained by two factors obtained. The rotated components matrix for all questions is shown in the table above. This matrix shows the factors for which each question was collected. Additionally, for each question, correlation values between the question and the factor to which the question belongs are shown in the table. The following designations for two factors were made according to the result of factor analysis:

Table 14. Factor Names

\begin{tabular}{|c|c|}
\hline Factor & Name of the Factor \\
\hline 1st Factor & General Characteristics of HUZEM \\
\hline 2nd Factor & Content of the Courses in HUZEM \\
\hline
\end{tabular}

\section{F. Correlation Analysis Regarding HUZEM Scale}

To analyze the correlation between the answers to the survey questions, SPSS (version 22.0) software package was used. Since the variables are in ordinal scale, the chi-square independence test was used in the analyses to determine whether there is a significant correlation between the two variables.

Chi-square analysis revealed that in HUZEM distance education system, the correlation between the students who are unable to have adequate communication with instructors want only formal education and those who think that they have adequate communication prefer the distance education system was thought to be statistically significant $(p<0.05)$. Similarly, the correlation was found to be statistically significant between the responses to the question of "Can you get sufficient help for your questions and requests in HUZEM system?" and formal training or distance learning preferences ( $p$ $<0.05)$.

The relationship between the responses of students given on the questions of the easy-to-use degree of HUZEM distance education website and the capability to use computer and internet in Hitit University being sufficient for distance education and the answers to the question of evaluation of HUZEM distance education system compared to face-to-face training in classroom was statistically significant $(\mathrm{p}<0.05)$. The students who think that HUZEM distance education system website is easy to use and the capability to use the 
computer and internet in Hitit University is sufficient for distance education stated that HUZEM distance education system is more efficient than the faceto-face training.

Students who wish to enroll in a higher education program providing education through distance education stated that the content of the course taken in HUZEM distance education being always accessible shortened their learning process. The correlation between the answers to these two questions is determined to be statistically significant $(p<0.05)$.

\section{v. CONCLUSION}

Many researches have been done related to distance education perception from past to present. Some of the results of these surveys are:

A research on distance education has conducted with 254 students at Boise State University. According to this study, students' distance education perceptions were analyzed. As a result of the study, participants reported that time and space flexibility is the most positive aspect of distance education. They stated that the most negative aspect of distance education is its taking more time than conventional education, and also it causes the learning mistakes. Besides, it is determined that the participants have generally been satisfied with the distance education. (Belcheir \& Cucek, 2002:11).

Ağır, Gür and Okçu have studied 238 primary school teachers' attitudes towards distance education. Teachers' perceptions of distance education were found to be positive. In addition, it was determined that their attitudes didn't change significantly according to gender and organization they work for. (Ateş \& Altun, 2008:141).

Tung and Chang, have studied the students' tendency to use the online distance learning environment. According to this study there are some important aspects influencing students' preference about online distance learning environment. These aspects are; students' computer self-efficiency feeling and web sites being preferable, useful, qualified for them. (Chang $\&$ Tung, 2008:81).

In this study, the efficiency of the distance education system used at Hitit University and the perceptions of students who use the system were examined with the survey method. In accordance with the responses to the survey questions, as a result of reliability analysis it was concluded that the survey 
is reliable. As a result of the survey analysis, about 15 percent of the students declared that they cannot use the distance education system since they do not use the Internet and it was determined that 31 percent of students, in total, do not use the HUZEM system. 42 percent of the students stated that distance education system as ineffective. $38 \%$ of students stated that both the distance and the formal education should be used together. In general, it is concluded that most of the students favor formal education. For the Distance Education Scale questions in the survey, size reduction was made by applying factor analysis. It is determined that Scale of Distance Education can be explained by a total of two factors according to the factor analysis results. These factors have been identified as the general characteristics of HUZEM and content of courses in HUZEM.

When the findings of the survey have been evaluated, it was considered that the main reasons for the negative thoughts against the distance education system applied in Hitit University for the first time are the lack of communication with the instructor online during the course presentation, inability to communicate with instructors outside of the course, for some of the students, not being able to use the Internet or HUZEM system, to be used to face to face education and prejudice against distance learning.

Analysis of the efficiency of common courses taught in Hitit University which is the purpose of this study and the results obtained for this purpose, the changes recommended to be made and problems encountered have been shared with HUZEM division. HUZEM division reported that they would seek solutions to the problems by evaluating the findings obtained. It is expected that it will help students get a better education in the case of necessary solutions being applied to the problems.

\section{REFERENCES}

AKMEŞE, Ömer Faruk. (2015), Uzaktan Eğitimde Ders İçeriği Oluşturma Platformu, Kırıkkale Üniversitesi Fen Bilimleri Enstitüsü Yayımlanmamış Yüksek Lisans Tezi, Kırıkkale.

AL, Umut \& Madran, R. Orçun. (2004), "Web Tabanlı Uzaktan Eğitim Sistemleri: Sahip Olması Gereken Özellikler ve Standartlar”, Bilgi Dünyası cilt.5, S.2, ss. 259271.

ATEŞ, Alev \& ALTUN, Eralp. (2008), "Bilgisayar Öğretmeni Adaylarının Uzaktan Eğitime Yönelik Tutumlarının Çeşitli Değişkenler Açısından İncelenmesi.” Gazi Üniversitesi Gazi Eğitim Fakültesi Dergisi, cilt.28, S.3, ss. 125-145

ANTALYALI, Ömer Lütfi. (2004), Uzaktan Eğitim Algısı Ve Yöneylem Araştırması Dersinin Uzaktan Eğitim İle Verilebilirliği, Süleyman Demirel Üniversitesi Sosyal Bilimler Enstitüsü, Yüksek Lisans Tezi, Isparta. 
BELCHEIR, Marcia J \& CUCEK, Mira. (2002), "Faculty Perceptions of Teaching Distance Education Courses." Research Report 2002-02.

CHANG, Su-Chao \& TUNG, Feng-Cheng. (2008). "An Empirical Investigation of Students' Behavioral Intentions to Use the Online Learning Course Websites." British Journal of Educational Technology, cilt.39 S.1, ss. 71-83.

COŞKUN, Cihangir. (2007), Uzaktan Eğitim için Web Tabanlı Bir Platform Gelistirilmesi ve Mekanik Derslerine Uygulanması. Yüksek Lisans Tezi. Gazi Üniversitesi, Ankara.

KAYA, Zeki \& ULUĞ, F. (1997), "Uzaktan Eğitim Yaklaşımıyla İlköğretim.” Uzaktan Eğitim Vakfi, Ankara.

LIONARAKIS, Antonis \& PAPADEMETRIOU, Demetra. (2003), "The Quality of the Learning Experience: A Comparative Study Between Open Distance and Conventional Education", Turkish Online Journal of Distance Education-TOJDE, cilt.4, S.2.

SHACHAR, Mickey \& NEUMANN, Yoram. (2003), "Differences Between Traditional and Distance Education Academic Performances: A Meta-Analytic Approach", International Review of Research in Open and Distance Learning, Cilt.4., S.2.

ŞEN, B., ATASOY, F \& AYDIN, N. (2010). "Düşük Maliyetli Web Tabanlı Uzaktan Eğitim Sistemi Uygulaması” [Bildiri], Akademik Bilişim 2010, 10-12 Şubat 2010, (ss. 1-12). Muğla: Muğla Üniversitesi.

VERDUIN, John R. \& CLARK, Thomas A., Çeviri: MAVIŞ, İlknur. (1994), Uzaktan Eğitim Etkin Uygulama Esasları, Anadolu Üniversitesi Basımevi, Eskişehir.

TÜİK. (2014), (erişim adresi http://www.tuik.gov.tr/PreHaber Bultenleri. do?id=15975), (erişim tarihi: 18 Kasım 2014). 
